\title{
THE KOSOVO CONFLICT AND THE CHANGING MIGRATION PATTERNS OF THE GORANI COMMUNITY: CONTINUITIES AND SHIFTS
}

\author{
Ivaylo Markov \\ PhD, Assistant Professor \\ Institute of Ethnology and Folklore Studies with Ethnographic Museum \\ Bulgarian Academy of Sciences, Bulgaria \\ Email: ivaylo.markov@iefem.bas.bg
}

\begin{abstract}
The Gorani are one of the archetypal migrant communities in the Balkans: migrations in search of livelihoods and better living conditions have become for them a structure of everyday life, influencing and determining the peculiarities of the local culture and the social organization since (at least) the middle of the nineteenth century. The periods of relatively voluntary labour mobility have alternated with those of compelled and forced resettlement. Firstly, the historical Balkan model of labour mobility known as gurbet, or under the SouthSlavic term pechalba, is shortly described. Then the contemporary movements following the Kosovo armed conflict in 1998-1999 are examined. The aim of the article is to study the dynamics of migration patterns and continuities and shifts in the concomitant social and cultural processes namely in the last two decades, within the context of post-conflict developments in the region.
\end{abstract}

Keywords: community rituals, Gorani, Kosovo conflict, labour mobility, migration, post-conflict developments, return visits, socio-cultural transformations

\section{INTRODUCTION}

Góra is a historical and cultural area located between the mountains of Sharr, Korab, and Koritnik, which was part of the Ottoman Empire until the Balkan Wars (1912-1913). Afterwards Kosovo became a part of Serbia - Gorski srez (county of Góra) - as a subdivision of the Prizrenski okrug (district of Prizren) (Toncheva 2012: 15). During World War I, Góra was conquered by the Central Powers and assigned to the Bulgarian (until May 1916) and to the AustroHungarian (until October 1918) zone (Avramovski 1985: 243-244). In 1925, when the state border between Albania and the Kingdom of Serbs, Croats, and Slovenes was finally established, the region was divided: the so-called Kukaska Góra (9 villages) was united to Albania, while Prizrenska Góra (19 villages) 
became part of the Kingdom of Serbs, Croats, and Slovenes. After World War II, within the Federal People's Republic of Yugoslavia (Socialist Federal Republic of Yugoslavia from 1963-1992), Prizrenska Góra was united to the Autonomous Region of Kosovo and Metohija within the Republic of Serbia, and two villages (Urvich and Jelovjane) became part of the newly established Federal Republic of Macedonia. Since 2008 it has been a part of the newly declared independent Republic of Kosovo. My current research focuses namely on the population of the Prizrenska Góra.

Today the Gorani are a Muslim community. The population adopted Islam at the times of the Ottoman rule in the Balkans; most researchers regard it as a process that started in the sixteenth-seventeenth centuries and continued until the middle of the nineteenth century (Jastrebov 1904: 95-96; Cvijić 1931: 175; Lutovac 1955: 41-42; Selishchev 1929: 406; Kanchov 1900a: 47). Until today, however, they have spoken a South-Slavic dialect, which is claimed to be part of the Serbian, Bulgarian, Macedonian or Bosnian languages. Because of the turbulent and complicated historical destiny of the region, in most cases studies have focused on the issues of origin and identity and have been related to ethnic, national or religious claims (Toncheva 2012: 73). Apart from the issues of origin and ethno-religious affiliation of the Góra population, other important research topics are not difficult to outline. The mobility and migrations of individuals and groups of people and the concomitant socio-cultural transformations are among them.

In this respect, it is important to mention that the Gorani are one of the archetypal migrant communities in the Balkans: for them migrations in search of livelihoods and better living conditions have become a structure of everyday life, influencing and determining the peculiarities of the local culture and the social organization since (at least) the middle of the nineteenth century. In the course of time, the periods of relatively voluntary labour mobility have alternated and intertwined with those of compelled resettlements. The aim of the article is to study the dynamics of migration patterns and continuities and shifts in the concomitant social and cultural processes in the last two decades, within the context of the post-conflict developments in the region.

The article starts with brief descriptions of my fieldwork and the process of data collection. Next, I review the migration history of the Gorani community. Then the contemporary movements following the Kosovo armed conflict in 1998-1999 are examined. As a result of the latter, significant changes in the main migratory characteristics and destinations can be observed. The increasing numbers of family migration and settlement in several Western European countries today replace the male temporary labour mobility within the ex-Yugoslav countries. The migration dynamics is influenced by complex processes taking 
place in post-conflict Kosovo - a number of political, economic, social, cultural, demographic, and psychological factors intertwine, determining the feelings of marginalization among many Gorani and influencing their aspirations and strategies for escaping from the country.

\section{FIELDWORK AND METHODOLOGY}

The paper draws on ethnographic first-hand data collected among the representatives of the Kosovar Gorani. The "multi-sited ethnography" approach (Marcus 1995) was applied. On the one hand, I visited selected villages ${ }^{1}$ in the region of Góra in Kosovo (migrants' origin area) three times at different times of the year (in total 25 days). The first fieldwork session took place in May 2018, in the week around St. George's Day (Đuren in the local dialect). It is the biggest fest in Góra, when most of the people working and living abroad come back to their native villages and the kin reunites. The second field research was conducted in the summer (end of July) of 2018, when many migrants were home for their annual holiday. The third visit took place in the second half of September 2018 so that I was able to see the region when there were only the permanent residents, and the migrant workers were abroad. On the other hand, I worked in Belgrade, Serbia (10 days, March 2018), and in Skopje, North Macedonia (5 days, September 2018), which are working and living places for many Gorani. ${ }^{2}$ In total, 77 interviews were conducted with people of different age, gender, education, and profession. Some people I interviewed twice or more, in some cases even in different localities. I also met and talked to the relatives of my interlocutors from Góra in Skopje and Belgrade and to those from Skopje and Belgrade in Góra. ${ }^{3}$

Although there was a questionnaire with basic research topics, I preferred to conduct semi-structured and unstructured interviews, in order to better outline people's evaluations, attitudes, and perceptions. I often encouraged my interlocutors to narrate their personal life experience, i.e., the biographical approach was also used. In their life stories people express their perceptions of successes and failures, and make generalizations about these, which helps them to explain the choices they have made in life (Brettell 2003: 24-25). Such ethnographic data allow the researcher to observe the changes in the cultural and social experience of the individuals, their points of view and daily practices, and the meanings people attach to their actions (Roberts 2002: 21). This approach takes into consideration the subjectivity of the narratives, yet finds them valuable as far as they reveal the respondents' opinions, dispositions, and attitudes (Lieblich \& Tuval-Mashiach \& Zilber 1998: 8-9). 


\section{MIGRATIONS OF THE GORANI: A HISTORICAL REVIEW}

Labour mobility out of the birthplace with the aim to earn the means of subsistence has been known for centuries among the population in a broad area of the Balkans. ${ }^{4}$ The model, according to which men earn money "away" or "abroad" (in a neighbouring region, a bigger town, another state/country or "somewhere in the Balkans"), but return seasonally or yearly to their home places and families, is known as gurbet/kurbet, or under the South-Slavic term pechalba/ pechalbarstvo (Hristov 2015: 31). The work engagements and activities are diverse - agrarian, such as harvesting and sheep breeding, or craft industry, such as construction, pottery, confectionery, and bakery (Palairet 1987: 25-37). There are even a number of common typological features that give cause for calling this model the "Balkan culture of migration" (Hristov 2010: 11).

Speaking particularly of the Gorani, in the early Ottoman period their basic economic activity was animal husbandry, and especially sheep breeding (Hasani 2011: 314). The region is mountainous and good arable land is scanty, but there is plenty of grazing land. During the winter, Goranian shepherds take their herds to the Adriatic and Aegean coastal areas and even Anatolia. These shepherds were part of the networks in the Ottoman Empire, which supplied the demand for meat, wool, hides, etc. Craft industry and labour mobility, however, were other important possible options for households to earn their livelihoods. In the second half of the nineteenth and especially in the first half of the twentieth century, the developing pechalba became a more important source of making a living, compensating for the gradual abandonment of animal husbandry. According to the interpretations of many researchers, the destruction of the agrarian system and the profound social crisis in the late Ottoman Empire, caused by the weakening of the centralized power and intensifying robbery, reduced sheep breeding in the region (Selishchev 1929: 405-406; Cvijic 1931: 134-135; Trifunoski 1952: 415-416; Ivanov 1993: 140-141; Hasani 1995: 155). The dissolution of the empire, the formation of the new countries in the Balkans, and the establishment of state borders throughout the region were also important reasons (Hristov 2015: 39-40; Toncheva 2012: 38-39).

So, it is documented that at the end of the nineteenth and the first half of the twentieth century many Gorani worked all over the Balkans - in Serbia (and later on in the Kingdom of Yugoslavia), Bulgaria, Romania, Greece, Turkey, and even in Egypt (Kanchov 1900b: 102; Cvijić 1931: 199; Lutovac 1955: 233). They specialised mainly in bakery, selling of dried nuts and fruits, pastry and ice-cream, as well as drinks such as boza $a^{5}$, salep ${ }^{6}$, lemonade, etc. Commonly these migrations were seasonal - the men left in the autumn (around St. Demetrios' Day) and returned in the spring for St. George's Day. Sometimes the work was 
year-round; then, especially in the cases of joint family households, their male members travelled on a rotational basis every several months. However, when the work destinations were more distant, some men were not able to return for several years. There are stories about such men, who could not recognize their children in the street when they came back; in other cases, the father found out that some of the children had died during his absence.

After World War II, many Gorani families left their homeland forever because of the new political situation and socio-economic relations and the imposed ideological framework, marked by Soviet-type collectivization and forced expropriation of property by the communist authorities (Hasani 2002: 37; 2007: 146). After the split between the Yugoslav and Soviet leaders, Tito and Stalin, the borders with the neighbouring Albania, Bulgaria, and Romania, who remained loyal Soviet allies, became practically impossible to cross. On the other hand, an agreement with Turkey for the expulsion of the "Turks" from the Federation to their "motherland" was signed in 1953 (Vickers 1998: 49). According to some narratives collected in Góra, in this period all migrant workers abroad had to decide whether to return home or to stay in their respective countries, separated from their families. Some remained in Bulgaria and Greece, but many went back to Góra. Soon after that, however, their property was nationalized. These developments pushed them to permanent emigration: based on their Muslim faith, many declared themselves as Turks and whole families left for Turkey through Macedonia (cf. Hasani 2007: 146).

The rest continued to live in harsh and poor economic conditions. As I have already mentioned, the roads to Greece, Bulgaria, and Romania as labour destinations were closed. The economic development of the Federation followed its own specific modified version of central socialist planning and industrialization after the split with Stalin. While most of the republics achieved economic growth, Kosovo within Serbia lagged behind in terms of economic development. In the 1960s the policy implemented on the Gorani community was marked by their social, cultural, and economic integration into the Yugoslav federation as a part of the Serbian nation. This additionally stimulated seasonal workers from the Gora region to turn their labour paths to the towns and cities within the Federation. There they worked as bakers, confectioners, and sellers of dried nuts and fruits in order to secure livelihoods for their households. From the end of the 1960s, with the signing of the official labour force recruitment agreements between the Yugoslavian government and some Western European countries, the Federation became a very active participant in the guest-worker programmes of the post-war Europe. Large numbers of the Gorani went abroad as Gastarbeiter in Western Europe. 
Going to pechalba as well as temporary working in Europe was a male path. Except for the people who left for Turkey, there were only a few cases when women and children accompanied the men working abroad. Commonly, women stayed behind and were taken care of by the husband's parents, brothers or unmarried sisters, in most cases living together in extended rural households. The migrants' wives took everyday care of the children but all the decisions concerning the work distribution, participation in rituals, visiting wives' relatives, education, etc., were prerogatives of the head of the household. The wives and children of the migrants were very cautious about their behaviour in order to maintain their reputation unblemished. They were put under close scrutiny by the local community and were expected to be quite humble and modest in their public appearance. Such behaviour was required in order to guarantee the honour of both the husband working abroad and the entire household. My elderly female interlocutors often told sorrowful stories about their earlier years of marriage, when they wrote letters to their husbands and waited anxiously for weeks and months to receive an answer. There were also the cases when, instead of a letter from the husband, they received sad news of his death.

Pechalba was inscribed in the local cultural model and was structural for everyday life. For men providing livelihoods for the near kin was a moral obligation and duty. In order to save more money, men working abroad restrained their consumption to a minimum. The gain was sent or brought to the household in Góra for covering the primary vital needs - food, medicines, clothing, and housing. As soon as the boys turned over 10, they would go away with their fathers or uncles in order to take up their profession and to start gaining for the household (Hasani 2007: 146). According to my field materials, the young boys were sent abroad during the summer holidays or after they had finished their elementary or secondary education in order to learn the professions. For instance, one of my respondents told me that after finishing the fourth year at school, he and his brothers were sent one after another to their father and uncles working in rotation in Samobor. There they completed their secondary education and worked during free time. The girls, however, were not allowed to work abroad or even go to school there; they helped with the housework and learned at home all the knowledge and skills needed for their future role as housewives.

Similar to other regions with strong pechalba traditions (Konstantinov 1964: 71-74; Hristov 2014: 113-114; Markov 2015: 179-181), around the moments of the pechalbar's departure and return, a ritual complex was performed. The pechalbars used to leave the village in groups in the autumn (commonly around St. Demetrios' Day). Some rituals of a protective nature, related to leaving home, took place. For example, a cup of water was spilt in front of the pechalbar, and 
his relatives wished him a safe trip and work as smooth as the water flowing before him. The spouse or the parents often gave him some objects from the home to carry with him, in order to preserve the thought of "here" while being "there". Relatives accompanied by a procession of specially engaged musicians, playing tupani (drums) and zurle (zourias) ${ }^{7}$ followed the men to a specific place at the edge of the village. From there they continued the procession to a closer or a more distant destination. After returning to the village, the relatives adorned the doors of the houses with freshly gathered flowers and green twigs, symbolizing the health of the pechalbar. His room was not to be swept this day, in order to avoid sweeping his luck away. Although the man was physically far from home, he remained within the thoughts of his relatives.

As the separation was a sad event, the physical return of pechalbars and their corporeal co-presence aroused happiness and excitement. The biggest fest in Góra (in the past, as well as today) was the week around St. George's Day. This was the time when most of the men working abroad came back to their native villages and the kin reunited. There was even the following widespread saying among the local population: Ke da si, da si, za Đuren doma da si! (Wherever you go, for St. George's Day you must return home!). Pechalbars were cordially welcomed home, again with music, dances, and a festive table. The fest ${ }^{8}$ lasted several days and was organized in a meadow near the village, where people were grouped based on kinship. This period was also appropriate for arranging marriage agreements between young girls and boys and their families, since most of the relatives on both sides were present and could participate in the rituals. According to the classical ethnographic data and my older interlocutors' narratives, the physical presence of all members of a particular kin network coincided with the period of wedding ceremonies and the circumcision ritual for little boys. These events occurred during the summer, mostly in July and August, and before the departure of the pechalbars.

As Polish ethnologist Karolina Bielenin-Lenczowska (2010: 520) notes, organizing such fests was possible and rational in the place of origin, since only the local people could comment on their customs, and the material and social aspects of fests and rituals could be observed and evaluated only by them. Thus, in the pechalba model, people structured their life in order to provide the family's well-being in Góra. All practices, and especially pechalbars' regular visits in the native places, aimed at their permanent return, which was a common social norm. Because of that, the trips were unilateral - only men working away travelled back and forth; older migrant-workers, no longer able to work, returned permanently to the village of origin. Furthermore, the idea of leisure was not central to the trips to Góra - during the stay the returnees participated in community rituals that defined the family-kin life cycle and helped to provide 
their households with resources and products for the time of their absence (for instance, they helped to make hay and fodder for the livestock).

\section{CONTINUITIES AND SHIFTS IN MIGRATORY PATTERNS}

In the 1970s and 1980s, some of the male migrant workers started to take their wives and children along with them due to the acquisition of self-contained flats and the overall improvement of living standards in their workplaces. These men were considered as breakers of the regular social order. In some cases, there were intra-family tensions and conflicts. Even in the early 1990s, this kind of family migration was still perceived as an exception, since most families were returning to their villages in the summer. All weddings were organised in the home village of the groom too, despite the fact that he or his fiancée were living away. According to my interlocutors in the village of Brod, for instance, there were more than 40 weddings every summer in the $1990 \mathrm{~s}$. The migrant's aim, even if he was living away with his wife and children, was to save enough money and to build his own house back in the native village, as it was stated above.

The Kosovo armed conflict in 1998-1999 was a turning point, which is deeply inscribed as a "place of memory" in the minds of my interlocutors. It was fought by the Kosovo Albanian rebel groups known as the Kosovo Liberation Army (KLA), whose guerrillas were calling for independence from Serbia, and the forces of the Federal Republic of Yugoslavia, which strived to keep Serbian control over Kosovo. ${ }^{9}$ Most of the Gorani took sides with the Serbs during the war, therefore they were institutionally and financially supported by the Serbian state in the post-conflict years. ${ }^{10}$ Because of that their relations with the Albanians in Kosovo were estranged, especially among the people directly involved in the Serbian parallel institutions (cf. Trupia 2019: 149-150). Despite the presence of the Kosovo Forces (KFOR), there were revenge attacks and violent actions against the Gorani and their property. For instance, the narratives pointed at burnt-down shops, demolished restaurants, etc., as well as the closing of some Serbs-owned enterprises where many people worked. Thus, large numbers of the Gorani lost their jobs, including those employed in the collapsed Serbian administrative systems (education, healthcare, and the police). Furthermore, the Gorani where repressed for speaking their mother tongue, and in many villages Serbian classes were dismissed and replaced with Bosnian ones ${ }^{11}$ (cf. Đorđević Crnobrnja 2014: 42-43).

According to the sources, until June 1999 there were around 17,000 Gorani in the region. As a result of all these political, socio-cultural, and economic reasons, and according to different estimations, between six and ten thousand 
people left Góra in the following years, and these were whole families, not men working abroad (Mladenović 2001: 43; Hasani 2002: 320). My interlocutors consider this period as an example of mass exodus. It was observed that emigrants had their preferences towards a specific destination for migration, based on the village they originated from. This perception derives from the earlier chain-labour mobility. For example, the families from Bachka, Dikance, and Mlike went in the greatest numbers to Serbia, mainly to Belgrade; those from Zli Potok settled in the autonomous Vojvodina province; families from Brod found new homes mainly in Skopje, Macedonia. However, all of them point to the NATO intervention as well as the socio-political changes in the post-war Kosovo as the turning point of the sudden replacement of the typical pechalba by the migration of entire families. In most of the cases, the settlement was defined by where the husband or other close relatives had already worked (see also Đorđević Crnobrnja 2014: 40; 2016: 90). Families who tried to escape by applying for asylum in Western European countries were also numerous. Some of my interlocutors and/or their relatives have settled and today live in Switzerland, Germany, France, Luxemburg, Sweden, Finland, etc.

In 2008 Kosovo declared independence, which was not recognized by Serbia. The declaration elicited mixed reaction internationally, and this issue still divides the international community. Currently, all Kosovo citizens need an official visa permit in order to work or reside legally in the EU countries (Schmidinger 2013: 126-127). It is practically impossible for one to travel with Kosovo documents to countries that have not recognized the state. Simultaneously, in the last years Kosovo has been considered a "safe third country". Because of this complicated international situation, some Gorani acquired Bulgarian passports in order to take advantage of the opportunity for free travel, which the country as an EU member provides. However, because of suspicion of corrupt practices, in 2014 the possibility of the Kosovo citizens applying for Bulgarian passports was abolished. Thus, the European migration rules and policies also influence migration patterns of the Gorani.

In the course of time, all these developments have led to new inequalities and tensions. The "wealthy" relatives from the West are constantly showing their "wealth" with their homes, cars, and other prestige objects. Many of those who are left behind are envious and irritated at the same time. Simultaneously, there is a great pressure on migrants to share their "wealth" with relatives who stayed behind and to help them to migrate as well. In the given circumstances, marriage has acquired additional significance. The legal papers of the future husband or wife now play a certain role. As marriages are still predominantly endogamous, Goranian girls and boys having legal status abroad have become preferable partners. This kind of family formation is another important tendency 
that strengthens the pattern of family migration. On the other side, several of my male interlocutors have chosen (again because of various reasons) to live and work in their villages in Góra. Most of them are in their thirties and forties and are not married yet. They speak with embarrassment, frustration, and disillusionment about their single status. According to their opinion, the young girls and women do not want to be married to men who are sheep-breeders, and therefore to live a rural life. They blame the common spread among the young girls, under the influence of family migration attitudes, to look for marital partners among the men working abroad, especially in Western Europe.

Thus, the ongoing processes of migration and mobility among the Gorani are complex and multi-layered. An important point to mention here is that during the last two decades the "family migration" existed along with the migration of single men (i.e., the pechalba model). Different types of migrants (labour, educational, marriage, refugees, etc.), living or only temporarily working in various countries, are interconnected economically and emotionally through family-kin ties, as they are connected with relatives and kin members in the places of origin. Gender and age dimensions are diverse as well - women and children also participate in migration processes. ${ }^{12}$ Young brides move due to marriage and many children are born and raised abroad. In some cases, women continue to be only housewives, taking care of the children's needs and upbringing. Many other girls, however, receive university education and afterwards work outside of their homes, which a few decades ago was inadmissible, according to the traditional norms and rules for what people ought to do and how they ought to behave.

Living abroad with the entire family changes the migrants' priorities: the focus turns towards earnings to provide for the nuclear family living there, while remitting money to villages of origin comes second. ${ }^{13}$ In the opinion of the people still living in Góra, the number of returning visits to the region has decreased over the years. As a cause they again see the armed conflict of 1998-1999 and the subsequent several post-conflict years - then the visits to the region were very dangerous, people were afraid of unexpected armed incidents. As a result, between 1999 and 2004, the return visits almost stopped, many missed the funeral of parents, others simultaneously regretted they were not able to marry in the village of origin (Góra) because of the war. As a result, even after the normalization of the situation in the region, visits became less frequent. For example, the number of wedding fests organised in the villages of origin has decreased; for instance, in Brod there are only three to five weddings yearly. Since generally most marriages are still endogamous, with preference for a partner originating from the same or neighbouring villages, ${ }^{14}$ this change could be easily explained. As such rituals bring together the kin, and most 
of the relatives who live away from the place of origin, yet in close localities abroad, the ritual is performed at the place of residence, which is convenient for the kinsfolk.

The second generation is another important topic for my interlocutors. According to the people residing in Góra, the children born and educated abroad will gradually lose the Gorani language, culture, and customs. All respondents living abroad argue that it requires special efforts to speak with their children in their mother tongue and to introduce them to the local Gorani culture and traditions. Aiming at preventing that, the parents take them to Góra during the summer vacation and stimulate their participation in local fests and rituals. Although nowadays teenagers and young adults get to know each other mainly via social media and virtual communication, their presence and participation in the celebrations of St. George's Day still has its significance and social role. Most of the children and young adults, however, do not perceive their parents' home villages, and Kosovo in general, as a potential place to live. The socioeconomic underdevelopment and instability is often mentioned as a cause. Belgrade, Skopje, and other cities and towns abroad are the places where they were born, where they grew up and went to school, where their friends are and where they have established job positions. Sometimes the children-migrants even voice their criticism about being obliged to visit the villages of their parents in Góra. Also, the construction of houses in the region often fails to meet the younger generation's standards (Schmidinger 2013: 129-130). In this respect, a transformation in the nature of the return visits can be observed - they are often described in terms of "relaxing" and "getting away" from the stressful routine life abroad. Generally, the future return to Góra does not define the trips anymore; the idea of leisure becomes more central. Another very significant tendency is particularly visible in the presented data: the visiting trips are not unidirectional; on the contrary - people from Góra also visit their children or other relatives abroad; they travel to be present at weddings or circumcision ceremonies there.

\section{CONCLUSION}

The Gorani community offers an interesting case study regarding the continuities and shifts in the migratory processes. Different and even opposite migratory tendencies (with regard to residence) have evolved over time. Both the Ottoman Empire and Yugoslavia with their extensive labour markets offered opportunities for temporary labour mobility to the cities for the rural mountain population, such as the Gorani. In the 1990s there were still relatively good opportunities 
for temporal work in Serbia. The Kosovo armed conflict (1998-1999), however, was the turning point. In the newly established social, political, and economic conditions of oppression, the former temporary migrant workers feared for their relatives left behind. The continuing tensions and crisis relationships with the Albanian majority stimulate and accelerate the family migrations and settlement processes abroad, which leads to significant socio-cultural transformations in the community. The presented data prove that the traditional family-kin relationships, behaviours, and gender roles have been modified. In the conditions of various patterns of migratory movements, the directions of visiting trips have changed significantly over time, with "stayers" and "leavers" travelling in both directions, challenging the established dichotomy between mobile migrants and static non-migrants (Janta \& Cohen \& Williams 2015: 587). Undoubtedly, this affects not only the everyday routines, but also the festivities and the observance of rituals - a problem that was just noted here, but would be researched further.

What kind of changes will occur in the overall migration patterns in the years to come? How do the migration practices and behaviour impact the processes of socio-cultural transformation and vice versa? These questions leave the topic open for future research, especially having in mind the dynamics of the international relations in the region and the aspirations of all countries in the so-called Western Balkans, including Serbia and Kosovo, to join the European Union.

\section{ACKNOWLEDGEMENTS}

The ethnographic data were collected in the course of the work on two research projects. The first one, titled "To work there, to marry here": Migrations and Family-Kin Dynamics in the Case of Gorani Community: Continuities and Shifts, was funded by the Programme for the Support of Young Researchers and PhD Students-2017 at the Bulgarian Academy of Sciences (Grant no 1723/24.07.2017). The second one was a bilateral Bulgarian-Macedonian project, Balkan Traditional and Contemporary Destinations and Patterns of Mobility, funded by the Bulgarian Academy of Sciences and Macedonian Academy of Sciences and Arts.

\section{NOTES}

1 Some of the conversations and interviews were conducted together with my colleagues Veselka Toncheva and Desislava Pileva (in the Góra region) and Violetta Periclieva (in the town of Skopje and the Góra region). 
${ }^{2}$ I worked in Dragaš, Leštane, Ljubovište, Dikance, Brod, Mlike, and Donja Rapča.

3 My interlocutors in Belgrade descend from Dragaš, Leštane, Dikance, and Mlike. In Skopje almost all of the respondents originate from Brod; I also talked with the Gorani from Urvič and Jelovjane - two villages located in the Republic of Northern Macedonia, but these narratives are not analysed in this text.

4 Michael Palairet writes that in the Balkans during the nineteenth century there were three large regions with concentrations of villages dispatching large numbers of people to work away: Central Bulgaria around Stara Planina and Sredna Gora; the Rhodope Mountains, especially to the north of Komotini; and the area extending from the western borderlands of Bulgaria and adjacent regions of southeast Serbia to Kosovo, Macedonia, and Pindus (Palairet 1987: 23).

5 Boza is a malt drink made by fermenting cereal flour, generally millet (maize, wheat or barley are also used). It is thick in consistency, has low alcohol content (around 1\%), and a slightly acidic sweet flavour. The drink is widespread in the Balkans, but also in Asia Minor, Caucasus, and Central Asia (Kazakhstan, Kyrgyzstan, Uzbekistan, etc.).

6 Salep is a drink made from the flour of the tubers of the orchid genus. These tubers contain a nutritious, starchy polysaccharide called glucomannan. The drink is widespread in the Balkans and the Middle East, especially in the Levant.

7 Wind instrument.

8 Here the fest itself and its ritual elements will not be explored in detail. For more see Antonijević 1974; Toncheva 2012: 94-104.

9 In March 1999, the KLA received air support from the NATO forces. In June 1999, after months of NATO bombing Belgrade and Serbian military sites, the United Nations (UN) approved the Security Council Resolution (UNSCR) 1244, which established the United Nations Interim Administration Mission in Kosovo (UNMIK) as the UN entity to oversee the resolution of the Kosovo crisis, and also identified the NATOled Kosovo Forces (KFOR) as the peacekeeping force to maintain order in the region (Dankaz 2018: 73).

10 The support continues after the Kosovo declaration of independence and even today there are some parallel Serbian institutions, such as schools, hospitals, etc.

${ }^{11}$ Currently there is only one gymnasium with Serbian as the language of tuition, and it is not located in the municipal centre Dragaš, but in the village of Mlike.

12 The ethnographic data show that girls who have finished secondary school in Góra, also go to receive their higher education abroad, often staying close to their relatives there.

13 There are different indicators of the shift in the priorities. These include the strong propensity for naturalization, the acquisition of real estate in the receiving country, and investments in the wellbeing and education of the children there (cf. Iseni 2013: 234).

14 The dynamics of marriage practices in correlation to migration and integration of the Gorani in Serbia (Belgrade and Tutin) has been studied in detail by Đorđević Crnobrnja (2018). 


\section{SOURCES}

Materials of interviews from 2018 in possession of the author.

\section{REFERENCES}

Antonijević, Dragoslav 1974. Đurđevdanski folklor kao obeležje specifičnosti i zajednice etničkih grupa Prizrena. [Folklore of St. George's Day as a Hallmark of the Specificity and Community of Prizren Ethnic Groups.] In: J. Vukmanovic (ed.) Rad XIV kongresa Saveza folklorista Jugoslavije u Prizrenu 1967. Belgrade: Savez udruženja folklorista Jugoslavije, pp. 193-202.

Avramovski, Živko 1985. Ratni ciljevi Bugarske i Centralne sile 1914-1918. [War Goals of Bulgaria and the Central Powers 1914-1918.] Belgrade: Institut za savremenu istoriju.

Bielenin-Lenczowska, Karolina 2010. Transnational Ties among Migrants and Their Families: The Case of Labour Migrants (Pechalbari) from the Republic of Macedonia to Italy. Kultura Polisa, Vol. 13-14, pp. 509-534. Available at http://kpolisa. com/KP13-14/kp13-14-VII-1-Karolina.pdf, last accessed on 13 December 2019.

Brettell, Caroline 2003. Anthropology and Migration: Essays on Transnationalism, Ethnicity, and Identity. Walnut Creek, CA: AltaMira Press.

Cvijić, Jovan 1931. Balkansko poluostrvo i južnoslovenske zemlje. Knjiga druga. [The Balkan Peninsula and South Slavic Lands. Second Book.] Beograd: Državna štamparija.

Dankaz, Musa 2018. The Gorani People during the Kosovo War: Ethnic Identity in the Conflict. Diss. (MA Thesis). La Salle University, USA. Available at https:// digitalcommons.lasalle.edu/cees_ma/1, last accessed on 13 December 2019.

Đorđević Crnobrnja, Jadranka 2014. Migracije iz Gore krajem dvadesetog i početkom dvadeset prvog veka. [Migrations from the Góra Region at the End of the 20th and the Beginning of the 21st Century.] Glasnik Etnografskog instituta SANU, Vol. 62, No. 2, pp. 35-46. DOI: 10.2298/GEI1402035D.

Đorđević Crnobrnja, Jadranka 2016. Crisis, Migrations, Culture: On the Influence of the Economic and Political Crisis on Migration Patterns of Gorani People and Changes to Their Culture. In: K. Roth \& A. Kartari (eds.) Ethnologia Balkanica, Vol. 18/2015. Cultures of Crisis in Southeast Europe. Part 1: Crises Related to Migration, Transformation, Politics, Religion, and Labour. Berlin: LIT Verlag, pp. 85-101. Available at https://www.researchgate.net/publication/313387839, last accessed on 13 December 2019.

Đorđević Crnobrnja, Jadranka 2018. Migracije, integracija i bračna praksa kod Goranaca. [Migration, Integration, and Marriage Practices among the Gorani.] Glasnik Etnografskog instituta SANU, Vol. 66, No. 3, pp. 581-600. https://doi.org/10.2298/ GEI1803581D.

Hasani, Harun 1995. Migracije stanovništva Gore. [Migrations of the Population of Góra.] In: Dr. Antonijević \& M. Radovanović (eds.) Šarplaninske župe Góra, Opolje i Serdska: antropogeografsko-etnološke, demografske, sociološke i kulturološke harakteristike. Belgrade: SANU, pp. 149-166. 
Hasani, Harun 2002. Migrations of the Population of the Šar Mountain Župa Góra. In: M. Bursać (ed.) Goranies, Muslims and Turks in the Šar (Sharr) Mountain Župas (Parishes) of Serbia. Belgrade: SASA, pp. 33-44.

Hasani, Harun 2007. Migrations of Goranies. In: D.T. Bataković (ed.) Kosovo and Metohija: Living in the Enclave. Belgrade: SASA, pp. 143-153. Available at https:// www.academia.edu/2976944/, last accessed on 13 December 2019.

Hasani, Harun 2011. Goranies: A Respected Minority in Serbia, a Persecuted Minority in Present-Day Kosovo. In: D.T. Bataković (ed.) Minorities in the Balkans: State Policy and Interethnic Relations (1804-2004). Special editions 111. Belgrade: SASA, pp. 311-322.

Hristov, Petko 2010. Gurbet on the Balkans: Traditional and Contemporary Forms. In: P. Hristov (ed.) Balkan Migration Culture: Historical and Contemporary Cases from Bulgaria and Macedonia. Sofia: Paradigma, pp. 28-43.

Hristov, Petko 2014. Seasonal Labour Migrations (Gurbet) in the Central Balkans and Their Associated Ritual Cycles. In: D. Parusheva \& L. Gergova (eds.) The Ritual Year 8. Migrations. Sofia: Paradigma, pp. 108-118. Available at https://www. siefhome.org/downloads/wg/ry/ry8.pdf, last accessed on 18 December 2019.

Hristov, Petko 2015. The Balkan Gurbet: Traditional Patterns and New Trends. In: H. Vermeulen \& M. Baldwin-Edwards \& R. van Boeschoten (eds.) Migration in the Southern Balkans: From Ottoman Territory to Globalized Nation States. IMISCOE Research Series. Dordrecht: Springer, pp. 31-46. Available at https:// www.academia.edu/12755084/, last accessed on 18 December 2019.

Iseni, Bashkim 2013. Albanian-Speaking Transnational Populations in Switzerland: Continuities and Shifts. Southeast European and Black Sea Studies, Vol. 13, No. 2, pp. 227-243. http://dx.doi.org/10.1080/14683857.2013.802174.

Ivanov, Iordan 1993. Zapadnite kraishcha na Makedoniia v etnografichesko otnoshenie. [The Western Parts of Macedonia in Ethnographic Terms.] In: P. Hr. Petrov (ed.) Nauchna ekspeditsiia $v$ makedoniia i pomoravieto, 1916 g. Sofia: Universitetsko izdatelstvo Sv. Kliment Okhridski; Voennoizdatelski kompleks Sv. Georgi Pobedonosets, pp. 136-150. Available at http://promacedonia.org/bg_1916/ bg_1916_2_8.htm, last accessed on 18 December 2019.

Janta, Hania \& Cohen, Scott A. \& Williams, Allan M. 2015. Rethinking Visiting Friends and Relatives Mobilities. Population, Space and Place, Vol. 21, No. 7, pp. 585-598. http://dx.doi.org/10.1002/psp.1914.

Jastrebov, Ivan Stepanović 1904. Stara Serbia i Albania. [Old Serbia and Albania.] Spomenik XLI, Srpska kraljevska akademija, Drugi razred 36. Beograd: Državna štamparija Kralevine Srbije. Available at https://archive.org/details/ IvanJastrebovStaraSrbijaIAlbanija/page/n1, last accessed on 18 December 2019.

Kanchov, Vasil 1900a. Makedoniia: Etnografiia i statistika. [Macedonia: Ethnography and Statistics.] Sofia: Balgarsko knizhovno druzhestvo.

Kanchov, Vasil 1900b. Góra. Trudove na balgarskoto prirodoizpitatelno druzhestvo, Vol. 1, pp. 99-103.

Konstantinov, Duško 1964. Pečalbarstvo. [Economic Migration.] Bitola: Naroden muzej. Lieblich, Amia \& Tuval-Mashiach, Rivka \& Zilber, Tamar 1998. Narrative Research: Reading, Analysis and Interpretation. Thousand Oaks \& London \& New Delhi: SAGE. 
Lutovac, Milisav 1955. Gora i Opolje - antropogeografska proučavanja. [Góra and Opolje - Anthropogeographic Studies.] Srpski etnografski zbornik, knj. LXIX Naselja i poreklo stanovništva, knj. 35. Belgrade: Srpska akademija nauka.

Marcus, George E. 1995. Ethnography in/of the World System: The Emergence of MultiSited Ethnography. Annual Review of Anthropology, Vol. 24, No. 1, pp. 95-117. http://dx.doi.org/10.1146/annurev.an.24.100195.000523.

Markov, Ivaylo 2015. Migracii $i$ socio-kulturna dinamika: albancite ot Republika Makedonija. [Migrations and Socio-Cultural Dynamics: The Albanians from the Republic of Macedonia.] Sofia: Gutenberg.

Mladenović, Radivoje 2001. Govor Šarplaninske župe Góra. [Dialect of the Šar Mountain Region Góra.] Srpski dijalektološki sbornik XLVIII. Belgrade: Insitut za srpski jezik SANU.

Palairet, Michael 1987. The Migrant Workers of the Balkans and Their Villages (18th Century - World War II). In: Kl. Roth (ed.) Handwerk in Mittel-und Südosteuropa: Mobilität, Vermittlung und Wandel im Handwerk des 18. bis 20. Jahrhunderts. Munich: SOG, pp. 23-46.

Roberts, Brian 2002. Biographical Research. Buckingham: Open University Press.

Schmidinger, Thomas 2013. Góra: Slawischsprachige Muslime zwischen Kosovo, Albanien, Mazedonien und Diaspora. Wien: Wiener Verlag für Sozialforschung. Available at https://www.academia.edu/4305148/, last accessed on 8 January 2020.

Selishchev, Afanasi 1929. Polog i ego bolgarskoe naselenie: Istoricheskie, etnograficheskie i dialektologicheskie ocherki Severo-zapadnoi Makedonii. [Polog and Its Bulgarian Population: Historical, Ethnographic and Dialect Essays about North-Western Macedonia.] Sofia: Izdanie Makedonskago nauchnogo instituta.

Toncheva, Veselka 2012. Nepoznatata Góra. [The Unknown Góra.] Sofia: Rod.

Trifunoski, Jovan 1952. Urvič i Jelovjane: dva torbeška sela u Pologu. [Urvich and Jelovjane: Two Torbesh Villages in the Region of Polog.] Glasnik etnografskog instituta SAN, Vol. 1, No. 1-2, pp. 409-419.

Trupia, Francesco 2019. Being a 'Good Personhood' in Kosovo: A Serbian Perspective from Below. In: I. Armakolas \& A. Demjaha \& A. Elbasani \& S. Schwandner-Sievers (eds.) Local and International Determinants of Kosovo's Statehood. Prishtina: Kosovo Foundation for Open Society, pp. 135-163. Available at http://kfos.org/ wp-content/uploads/2019/09/KFOS_Local-and-International-Determinants-ofKosovo\%E2\%80\%99s-Statehood-WEB.pdf, last accessed on 8 January 2020.

Vickers, Miranda 1998. Between Serb and Albanian: A History of Kosovo. London: Hurst $\&$ Co.

Ivaylo Markov is Assistant Professor (PhD) at the Institute of Ethnology and Folklore Studies with Ethnographic Museum at the Bulgarian Academy of Sciences, Bulgaria. His main research areas are ethnology of mobility and migrations, ethnology of borders and border regions, and cultural and natural heritage.

ivo.d.mark@gmail.com 